\title{
A Public Value Based Framework for Evaluating the Performance of $e$-Government in China
}

\author{
Wenlin Bai ${ }^{1,2}$ \\ ${ }^{1}$ Key Laboratory of Data Engineering and Knowledge Engineering of the Ministry of Education, Renmin University of China, Bei- \\ jing, China; ${ }^{2}$ School of Information Resources Management, Renmin University of China, Beijing, China. \\ Email: wenlin-bai@163.com
}

Received May, 2013

\begin{abstract}
Much research has been done on evaluating the performance of e-government in China, but comprehensive pictures of research done on evaluation of performance of e-government can hardly be found in the Chinese literature. Besides, there are few theories to support the research and practice in evaluation. By analyzing existed literature, the paper proposes a conceptual framework for evaluating performance of e-government based on public value perspective. Delivery of public services, effectiveness of public organization and development of trust are identified and selected as three basic public values for analysis.
\end{abstract}

Keywords: Evaluation of Performance of e-Government; Public Value; Conceptual Framework; China

\section{Introduction}

"Electronic Government” (or in short “e-Government”) essentially refers to 'The utilization of IT, ICTs, and other web-based telecommunication technologies to improve and enhance on the efficiency and effectiveness of service delivery in the public sector.' (Jeong, 2007)[1]. With the development of information and communication technologies (or in short ICT), the concept of electronic government becomes more and more popular all over the world. In the background of information and knowledge economy, the construction of E-government has become a necessity [2-3]. However, with the constant pressure of investment on e-government, evaluating the performance of e-government becomes urgent. To the government, it has provided an effective way to reduce the operating costs for government and at the same time, to enhance the administrative ability of government [4]. To the citizens, evaluation of performance of e-government has provided an opportunity for citizen to participate in the e-government services and to increase the availability of government information and to improve their public services which will be beneficial to meet the citizens' needs [5,6].

Many e-government projects and research have been done in China, however, e-government performance research in China are either from the perspective of government agencies or from the perspective of citizens, no convergence of both as an integrated whole and lacks of theoretical support. This paper recommends adoption of concept of public value as theoretical support to the evaluation. In this paper, the concept of public value refers to a holistic approach to evaluate the effectiveness and efficiency of public services (Moore, 1995)[7]. Firstly, this paper has reviewed representative Chinese and English literature on "evaluation of performance of e-government” from CSSCI, ProQuest database, EI, SCI, SSCI, ISTP, ISSHP citied journals. Representative theory, strategies practices have been selected for study. Then based on literature review and meta-synthesis, a new conceptual framework for evaluation of e-government performance is put up.

\section{Literature Review}

Literature shows there is little research on evaluation of performance of e-government under the perspective of public value in Chinese literature. However, the concept of public value has been aroused much attention and has been widely used in the designing of framework for e-government performance evaluation in English literature. Figure 1 shows an overview of five representative papers:

The five representative papers all share same concept of public value, but each has different advantages and limitations. The first paper focuses on high quality of services, outcomes and trust with limitations on trust not fully discussed. (Keams, 2004)[8].The second paper focuses on the operating efficiency of government, the publicity and transparency of public agencies, the public 
percep- tion on public service politics and user. It has limitations on not enough attention to the impact of e-government on information society (E-GEP, 2006)[9]. The third paper focuses on the public value created by portals of Russiagovernment, but limitations are that the portals cannot represent the whole e-government performance (Golubeva, 2007)[10]. The fourth paper focuses on aspects of service, outcomes and trust, but "trust" is also not fully discussed, which are similar to the drawbacks of the first paper Heeks, 2008)[11]. The fifth paper focuses Nan integrated frame workc onsists of multiple aspects of public value, including delivery of public services, achievement of outcomes, development of trust and effectiveness of public organization as shown in Figure 2. The framework was justified in Sri Lanka, it has both practical and theoretical significance for e-government performance evaluation. Each of the above approach provides different concerns on what consists of public value. Deng's view on public values is the most comprehensive one, but the justification based on Sri Lanka is limited by the country's experience, whether it can be applied to China need to be verified [12-16].

Taking prons and cons of the five representative perspectives into consideration, they have providedfollowing implications to the formulation a conceptual framework for China:

Firstly, evaluation perspective should be comprehensive, from both government agencies and citizens sides, rom government side, quality of public service and efficiency should be focused on [17]. From the citizens' side, satisfaction and the attitude towards e-government should be clearly defined.

Secondly, evaluation indicators should be comprehensive[18]; various views on what consists of public value from five representative papers could be a good reference, particularly Professor Deng's comprehensive framework.

Thirdly, the framework should be based on Chinese practice and goals of e-government in China.

\section{A Conceptual Framework for China}

Taking the above implications into consideration, this paper proposes an adaption of Hepu Deng's conceptual framework for China, as shown in Figure 3:

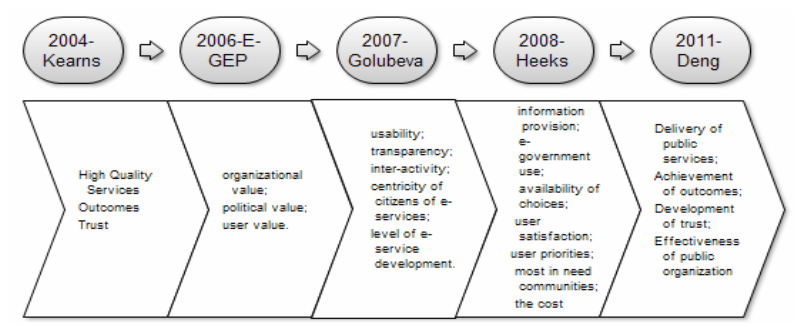

Figure 1. An overview of the evolution of performance of e-government under public value perspective.
The proposed framework as shown in Figure 4, including (A) delivery of public services (B) effectiveness of public organization(C) development of trust. Each public value creation part also consists of several subordinate elements which can concretely evaluate the public value, as shown in Table 1. These key subordinate elements are from the existed frameworks of other scholars, taking the above implications into consideration for selection.

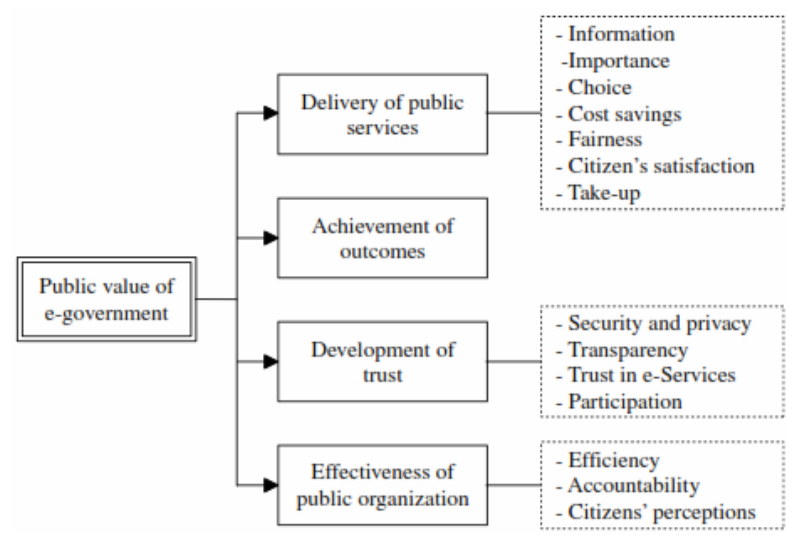

Figure 2. Conceptual framework for evaluating public value of e-government (Deng, 2011).

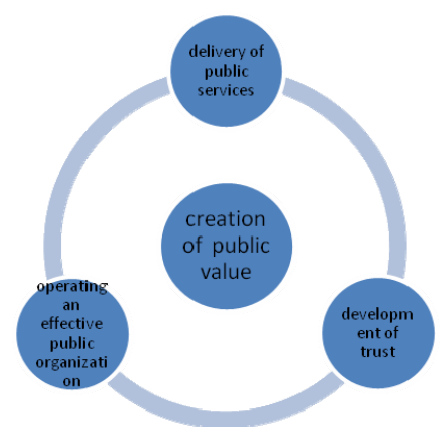

Figure 3. The public value-based framework for evaluating the performance of e-government.

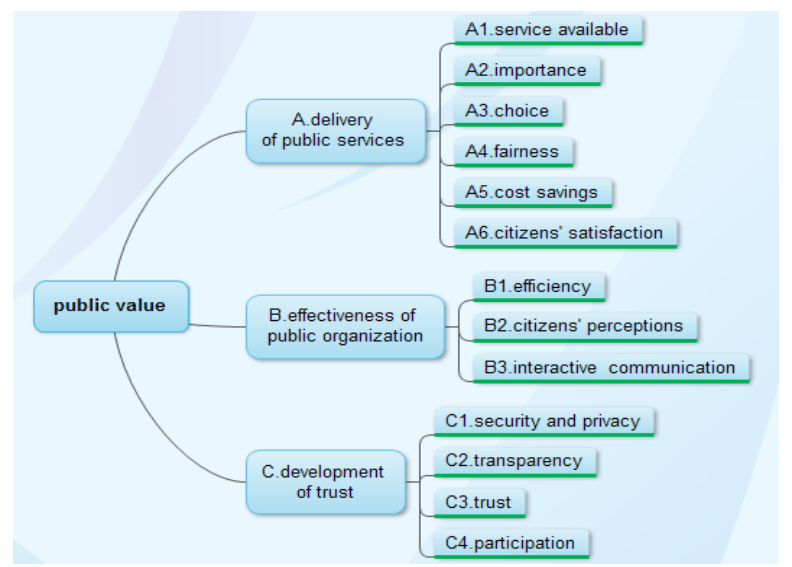

Figure 4. Indicators associated with the attributes of the conceptual framework. 
Table 1. Origin indicators for the public value-based framework for evaluating the performance of e-government[19].

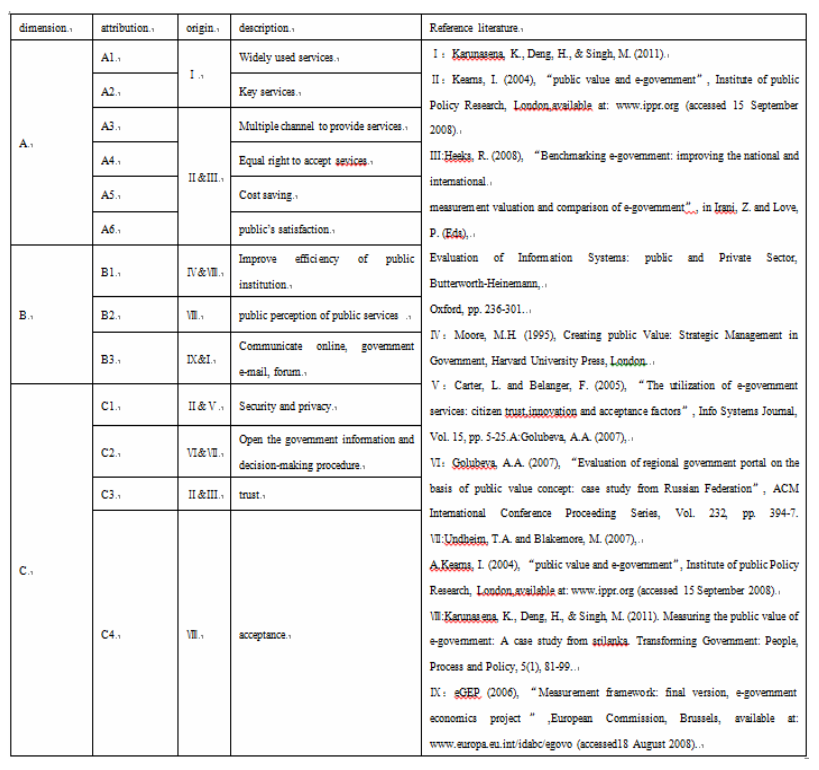

The delivery of public services has six attributes: (A1) service availability (A2) importance (A3) choice (A4) fairness (A5) cost savings(A6) citizens' satisfaction. These attributions are inherited from Kearns (2004) and Heeks (2008)'s perspectives on public service, at the same time, adding availability and importance of information toavail- ability and importance of public service, as a result, the wholeness of performance of e-government would be better viewed. Furthermore, compared to Deng's description on "cost saving", the "cost" in new framework not only means the cost saving made by public, but also include the cost saving made by government agency.

Effectiveness of public organization has three attributes, (B1) efficiency (B2) citizens' perceptions (B3) interactive communication. Firstly, concept of "efficiency" is adopted from the explanation of Moore (1995) in which the efficiency of organization was discussed. Secondly, "interactive communication" is learned from the explanation of "accountability" in the framework on economic assessment of e-government of e-GEP (2006), which emphasizes the interactive communication between the public and government. Thirdly, the "citizens' perception" is from indicators of positive and negative effects made by government agency to the public, which focuses on the promotion of organization driven by egovernment from the perspective of the public from Deng's paper.

Development of trust has four attributes: (C1) security and privacy (C2) transparency (C3) trust (C4) participation. What should be mentioned here is that the attribution "transparency" is integrated with the thought of government affairs openness, which will be one of the direct indicators for assessing the performance of e-government.

In this framework, both government agencies and citizens' perceptions have been taken into consideration, and the multiple dimensions and attributes of public value and their possible use in China have been fully taken into consideration, adaptable to overall situation of e-government practice in China.

\section{Conclusions}

Evaluation of performance of e-government is a comprehensive adaptive system, which should consist of both government and citizen actions and their feedbacks for continual improvement. To overcome the separated and isolated evaluation studies and practices in China, this paper recommends a holistic view of public value to formulate a comprehensive framework for evaluating the performance of e-government. This paper is limited to conceptual framework formulation based on literature review; justification study done by surveys will be discussed in another paper.

\section{Acknowledgements}

This work is partly supported by China-US Fulbright Research Program for Xiaomi An.

\section{REFERENCES}

[1] Golubeva and A. Anastasia, "Evaluation of Regional Government Portals on the Basis of Public Value Concept: Case Study from Russian Federation,” Proceedings of the 1st International Conference on Theory and Practice of Electronic Governance,”ACM, 2007.

[2] Carter, Lemuria and F. Bélanger, “The Utilization of E government Services: Citizen Trust, Innovation and Acceptance Factors,” Information Systems Journal, Vol. 15 , No. 1, 2005, pp. 5-25. doi:10.1111/j.1365-2575.2005.00183.x

[3] G. F. Chen and C. C. Wang, "On E-government Performance Evaluation in the Perspectives of Innovation,” 2011 International Conference on Information Management, 2011, pp. 172-175.

[4] EGEP, “Measurement Framework: Final Version, E-government Economics Project," Retrieved October 11,2012,fromhttp://www.umic.pt/images/stories/publicac oes200709/D.2.4_Measurement_Framework_final_versio n.pdf, 2006.

[5] European Commission, "Measurement Framework Final Version: E-Government Economics Project," Retrieved June 20, 2009, from. http://www.epractice.eu/files/ media/media1299.pdf, 2006.

[6] R. Heeks, "Benchmarking E-government: Improving the National and International Measurement Evaluation and Comparison of E-government,” In Z. Irani, \& P. Love (Eds.), Evaluating information systems: Public and 
private sector. Oxford: But-terworth-Heinemann, 2008, pp.236-301.

[7] J. C. Hai and Ibrahim, "Fundamental of Development Administration,” Selangor: Scholar Press. ISBN 978-967-5-04508-0, 2007.

[8] K. Karunasena and H. Deng, “A Conceptual Framework for Evaluating the Public Value of E-government. Proceedings of the 20th Australasian Conference of Information Systems,” Retrieved September 28, 2012, from. http://aisel.aisnet.org/acis2010/13/, 2009.

[9] K. Karunasena and H. Deng, "Exploring the Public Value of E-government: An empirical study from Sri Lanka,” Proceedings of the 23rd Bled e-Conference e-Trust: Implication for the Individuals, Enterprises and Society, 2010.Retrieved October 18, from. http://aisel.aisnet.org/bled2010/21/

[10] K. Karunasena and H. Deng, “A Citizen-Oriented Approach for Evaluating the Performance of e-Government in Sri Lanka,"International Journal of E-government Research, Vol. 8, No. 1,2012, pp. 44-63.

[11] K. Karunasena, H. Deng and M. Singh, "Measuring the Public Value of E-government: A Case Study from Srilanka,"Transforming Government: People, Process and Policy, Vol. 5, No. 1, 2011, pp. 81-99. doi:10.1108/17506161111114671

[12] K. Karunasena and H. Deng, "Critical Factors for Evaluating the Public Value of E-government in Sri Lanka," Government Information Quarterly, Vol. 29, No. 1,2012, pp. 76-84. doi:10.1016/j.giq.2011.04.005

[13] I. Kearns, "Public Value and E-government,"Retrieved October 22, 2012, from.
http://www.ippr.org/uploadedFiles/projects/Kearns_Publi cValueandeGovenrment_ippr.pdf.

[14] M. H. Moore, "Creating Public Value: Strategic Management in Government," London:Harvard University Press, 1995.

[15] Saheer., H. -Jaghoub, M. Yaseen and Hourani, "Evaluation of Awareness and Acceptability of Using e-Government Services in Developing Countries: The Case of Jordan,” Electronic Journal Information Systems Evaluation, Vol.1, 2010, pp.1-8.

[16] The FEA Program Management Office, "FEA Consolidated Reference Model Document Version 2.3,” 2007. Retrieved october 2, 2012 from. http://www.whitehouse.gov/sites/default/files/omb/assets/ fea_docs/FEA_CRM_v23_Final_Oct_2007_Revised.pdf

[17] B. Hermana and W. Silfianti, "Evaluating E-Government Implementation By Local Government: Digital Divide In Internet Based Public Services In Indonesia," International Journal of Business and Social Science,20113, pp. 156-163.

[18] G. C. Reddick, "Factors that Explain the Perceived Effectiveness of E-Government: A Survey of United States City Government Information Technology Directors," International Journal of Electronic Govenment Research,2009, pp. 1-15.

[19] S. A.-J. Hussein, A.-Y. Mouath and A.-Hourani, "Evaluation of Awareness and Acceptability of Using E-government Services in Developing Countries: The Case of Jordan,” Electronic Journal Information Systems Evaluation, 2010, pp. 1-8. 